\title{
A Study on the Determinants of FDI from Korea: Does ODA Attract FDI?
}

\author{
Geon Woo Park
}

\begin{abstract}
The purpose of this study is to analyze the determinants of Foreign Direct Investment in countries. An attraction of FDI makes job creation, economic revitalization and the transfer of advanced technology to the country. It would be the base of development that affects macro-economics. In other words, that can be seen as a direct economic growth driver. In order to attract investment, the countries compete each other strategically. There are a lot of researches which has been carried out for FDI. However, this study was conducted due to the insufficiency of the research about ODA and governance factors regarding the relationship of the FDI. For this study, I employed the fixed-effected model and random-effected model based on panel data for countries. In this study, diverse variables such as economic variables, policy variables and governance variables were employed. The findings from this study show that most of variables such as governance, political factor and economic factor have consistent signs with significancy. ODA variables have a impact on FDI.
\end{abstract}

Index Terms-Foreign direct investment, official development assistance, governance, Korea, panel analysis.

\section{INTRODUCTION}

For many years, the Korean government has been unremitting efforts for quantitative and qualitative expansion of ODA in international aid. It is reported that the Korean annual aid has increased and records the number one in the rate of increase in the size of the period of 2008-2012 by Ministry of Strategy and Finance. It is much higher than the $0.8 \%$ is the average of the DAC member countries which achieved performance of $18.8 \%$ rate. That is based on the experience of economic development that has grown to donor countries from aid donor countries in the international community, the Korean government going efforts for mutual cooperation for the sustainable development. OECD/DAC(2003) to see the need for create an environment for trade activation and investment promotion for poverty eradication and economic growth of the recipient countries need assistance for the infrastructure of the economy and society. In this respect, FDI and ODA of Korea are showing a significant increase in the past few decades. This means that the role of Korea in the international community is increased further. In conjunction with this trend, Dambisa Moyo's book called "Dead Aid", aid to Africa of OECD/DAC adversely affects rather inhibit the development of social and economic development potential [1]. This would be able to see assistance inefficient assistance is not taking into consideration the financial and social infrastructure and improvement of trade balance and attracting FDI has been

Manuscript received July 1, 2014; revised September 2, 2014.

Geon Woo Park is with Yonsei University of Korea (e-mail: a9hero@hanmail.net). enforcement. That is, through the establishment of infrastructure, it is one that private investment will follow in subsequent manner. Although the importance of the issue, research about overseas investment of the company through the aid policies of South Korea is insufficient relatively. As a result, we expect to be able to present the implications for the proposed expansion of our companies through ODA strategic policy of the South Korean government in the future.

\section{FDI THEORY AND LITERATURE REVIEW}

\section{A. Foreign Direct Investment}

Foreign Direct Investment is intended to create a profit and corporate by directly involving in the management of foreign companies. It is possible to see the investment approach to transfer to the local overall resources and expertise capital management techniques and techniques which are factors of production owns proprietary. This is done by establishing a new company in a foreign country to participate in the direct management.

\section{B. The Determinants of FDI}

Research on FDI, have been performed so many. Advanced studies on the determinants have also been discussed variously based on the each theory. These theories about FDI are integrated through the eclectic theory of Dunning [2]-[4]. This theory has been evaluated theoretically that is most universal in the description and motivation of FDI.

\section{Foreign Direct Investment through Official Development Assistance}

Construction of social and economic infrastructure through the aid can make a foundation for development and improvement of the trade environment and attract foreign investment in the long term. As a result, companies can through overseas expansion to pursue corporate behavior strategic for the development of symbiosis between the two countries of the host country and home country investment in following manner. There is no effect relationship in result of the theory [5]-[8]. On the other hand, aid has a positive impact in attracting FDI [9]-[12]. In this study, based on the discussion of these, what is the correlation with the foreign investment of Korean companies, especially aid of the South Korean government, to be analyzed empirically?

\section{ForeIGN DIRECT INVESTMENT OF KOREAN}

Above graph shows the total amount of foreign direct investment by geographic location of the Korean companies. Actual investment to Asian countries adjacent to South Korea 
was the highest and its ratio was 45.06 percent average for the period 1995-2013. And it was $23.57 \%$ in North America, and $16.92 \%$ in Europe. Because of the global financial crisis of 2008, investment in Asia fell sharply, but the same time, investment in Europe and North America has increased rather. The Fig. 1 also showed a lowest investment with $1.31 \%$ to Africa. The China and Japan performed strategic aid and investment through resource diplomacy in African countries, while the Korean didn't yet. The Korean companies had invested most in Asia, North America and Europe. They reacted to fluctuations with the various economic conditions like downturn and global economic crisis. Although Korean government and companies recognized the problem of status for ODA and FDI, improvement for this situation was still insufficient.

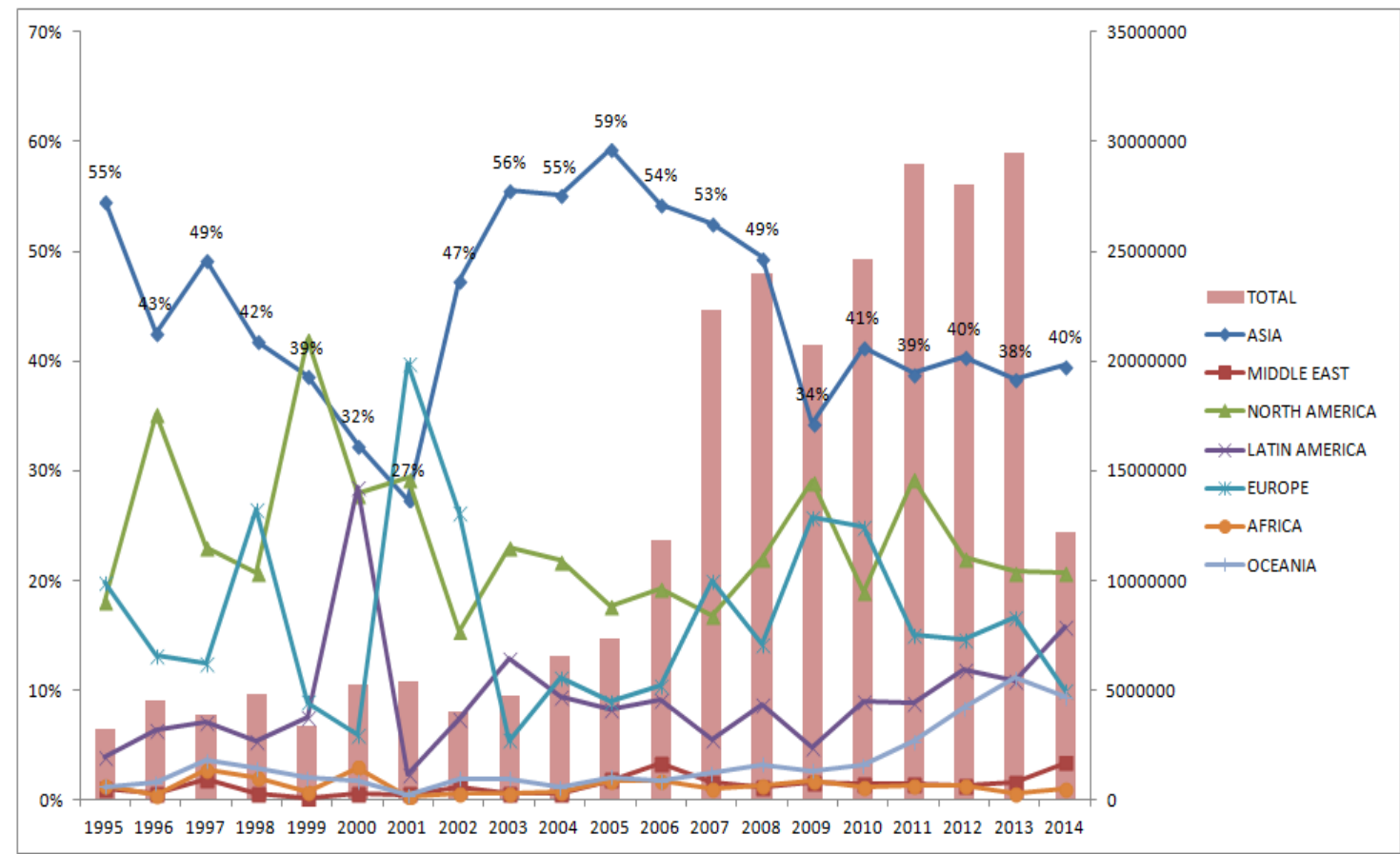

Fig. 1. Foreign direct investment of Korean companies by region.

\section{RESEARCH MODEL AND HYPOTHESIS}

In this study, I try to analysis utilizing panel data obtained by combining the data of the cross- section and time-series data. In the regression analysis using panel data, as time passes, there is a high correlation in determinant of FDI amount flowing into the country. It is used in many comparative studies to analyze. That is, the panel analysis, it may be the most effective way in the empirical analysis. In this study, diverse models such as pooled-OLS, fixed effects model, probability effect model are utilized to analyze panel data.

$$
\begin{gathered}
\ln (\mathrm{FDI}) i, t=\alpha+\beta 1 \ln (\mathrm{ODA}) i, t+\beta 2(\mathrm{GOV}) i, t \\
+\beta 3(\mathrm{AGR}) i, t+\beta 4 \ln (\mathrm{LAGF}) i, t+\beta 5(\mathrm{ALLF}) i, t \\
+\beta 6(\mathrm{INF}) i, t+\beta 7 \ln (\mathrm{POP}) i, t+\beta \ln (\mathrm{GDP}) i, t+\varepsilon . \\
\text { Fig. 2. Research model. }
\end{gathered}
$$

\section{A. Dependent Variable}

Dependent variable in this study is the annual investment of Korean companies to invest in host countries, which were analyzed on the basis of data collected officially from the Export-Import Bank of Korea. This data is indicative of the size of the investments that are reported by Korean company. The period is from 1995 to 2013.

\section{B. Independent Variable}

The independent variable in this study will be described focusing on the variables based on characteristics of individual countries to be analyzed. The independent variables were analyzed separately into four categories that ODA policy, governance factors, political factors, such as economic factors primarily t- 1 point. This is to be analyzed by most of adjusting the result of the distortion.

\section{1) Official development assistance policy}

For the relevance of FDI and ODA, it does not present a consensus to each scholar. But, in general, if awarded country assisted by the donor, and agree generally with regard to the assumption that private investment country are run together. In this study, to be analyzed to target the total amount of ODA the Korean government has made. I utilize the ODA data with CRS data of OECD STAT which the South Korean government, had officially reported annual.

- Hypothesis1: The aid of South Korea will give a positive impact to the increase in FDI.

\section{2) Governance factor}

As a typical index of governance factors, there is a World Governance Index, which is constituted by level of accountability and voice, government efficiency, corruption control, regulatory quality, responsibility, law compliance [13]. WGI can be viewed as factors that could affect the general discussion of foreign investment sufficient as possible as an indicator of a very useful overseas investment. Also, this indicator is very reliable as governance indicators. Because a number of researchers utilized [14]-[18]. In this study, we use the average value for the year of governance six 
variables.

- Hypothesis2: Governance of the high level of recipient will be able to attract foreign investment more.

\section{3) Political factor}

The degree of risk of forfeiture, political stability of the host country, political freedom, private property, the degree of democracy, these political factors used from existing research associated with FDI [19]-[22]. In this study, I am going to discuss on the basis of the countries that have signed an agreement with South Korea. Signing the contract, it may be classified as economic necessity and diplomatic or agreement in the trade sector and economy between the two but, like diplomatic achievements and expansion of investment between the two countries through economic exchange, which is provided for the purpose of a macroscopic dimension. In this study, we analyzed the target year, which took effect in fact the agreement.

- Hypothesis 3: The bilateral economic agreements of Korea government will be positively associated with the foreign investment expansion of Korean.

\section{4) Economic factor}

Economic growth, inflation and the size of the market may affect foreign investment. These variables have been used as independent variables from many researchers traditionally. In addition, in many studies associated with FDI, it has emphasized the importance of economic factors.

- Hypothesis 4a: The deregulation of the Korean government for the companies is positively associated with increase of FDI.

- Hypothesis $4 \mathrm{~b}$ : The degree of inflation of recipient is negatively associated with the increase of FDI.

- Hypothesis 4c: The GDP is positively related to increase of FDI.

- Hypothesis 4d: The investment of other countries is positively associated with increase of FDI.

- Hypothesis 4e: The previous investment of Korean companies is positively associated with increase of FDI.

\section{EMPIRICAL ANALYSIS RESUlt}

In the above analysis, it was possible to know the relationship between the influences of the total amount of FDI is the dependent variable factors. First, development assistance of the South Korean government shows the relationship between positive $(+)$ in foreign investment in Korean companies. Pooled - According to the analysis of stochastic effects model and OLS, it is possible to see ODA increases 1 percent, to a $3.7 \%$ increase also about foreign investment in Korean companies. However, the effect of ODA has been found to be the relationship of positive (+), there is no statistical significance in the fixed effects model. On all models, the level of governance of investment host countries were obtained significant results in the direction of the positive (+). Also ratification of economic agreements can be seen in the political factors and South Korea and host country of the individual, significant results came out in the direction of the positive (+) on all models. This can be seen as clearly as the fact that the number of economic agreements ratified Korea increases FDI Korean companies that have increased. On the other hand, in the case of post 2005 variable is the empirical analysis to that overseas expansion of Korean companies, the Korean government has made significant deregulation starting from the 2005, statistical significance was derived only in the fixed effects model. Finally attract investment from all countries of the world and investment in the previous year of Korean companies are major economic factors were found to affect aggressive investment of Korean companies. In the case of inflation, negative as in the hypothesis (-) relationship was observed, but it was not statistically significant. And is a control variable, the case of investment in the previous year is a major economic variables, it became clear as the biggest factor in the explanation of FDI in Korea. Investment in the previous year is increased $1 \%$, to be increased by about $64 \%$ with a probability effect model, is about $26 \%$ in the fixed effects model was found that the investment for the next fiscal year (see Table I to Table V).

TABLE I: VARIABLES DESCRIPTION

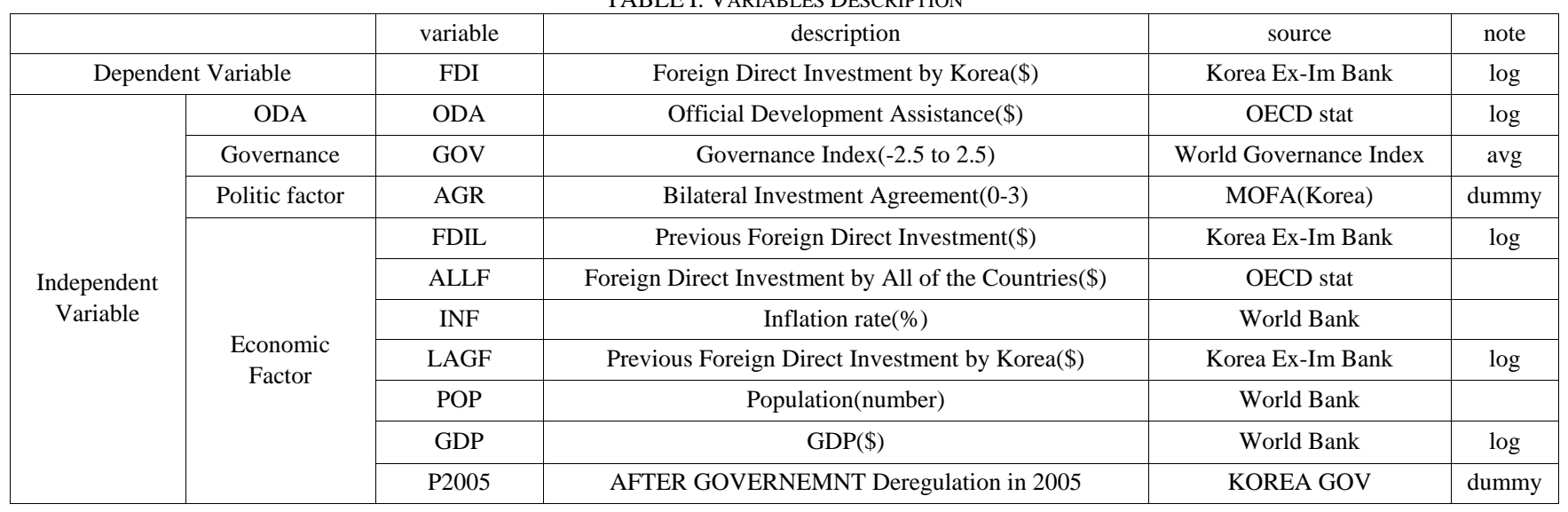

TABLE II: DESCRIPTIVE STATISTICS

\begin{tabular}{lccccc}
\hline \hline \multicolumn{1}{c}{ Variables } & Number of observations & Mean & Standard deviation & Min & Max \\
\hline YEAR & 3438 & 2003.5 & 5.188882 & 1995 & 2012 \\
REGION & 3438 & 2.623037 & 1.445293 & 1 & 6 \\
COUNTRY & 3438 & 96 & 55.14422 & 1 & 191 \\
FDI & 3438 & 5.536137 & 3.925411 & 2.302585 & 16.62274
\end{tabular}




\begin{tabular}{llcccccc} 
ODA & 3438 & 2.443327 & .4235495 & 2.302585 & 5.937853 & 1.21 & 0.826467 \\
GOV & 2659 & -.0532524 & .9138821 & -2.491062 & 1.986065 & 3.31 & 0.302452 \\
AGR & 3438 & .7012798 & .9026219 & 0 & 3 & 2.42 & 0.413122 \\
P2005 & 3438 & .3888889 & .4875689 & 0 & 1 & 1.18 & 0.850622 \\
ALLF & 3219 & $6.01 \mathrm{e}+09$ & $2.37 \mathrm{e}+10$ & $-2.83 \mathrm{e}+10$ & $3.40 \mathrm{e}+11$ & 1.34 & 0.744497 \\
INF & 2947 & 21.66509 & 460.4841 & -16.11733 & 24411.03 & 1.00 & 0.996270 \\
GDP & 3308 & 23.4214 & 2.4432 & 16.21574 & 30.41878 & 7.83 & 0.127668 \\
POP & 3420 & 15.41161 & 2.164246 & 9.129889 & 21.02389 & 6.16 & 0.162293 \\
\hline Mean VIF & & & & & 2.94 \\
\hline
\end{tabular}

TABLE III: CORRELATION

\begin{tabular}{|c|c|c|c|c|c|c|c|c|c|c|}
\hline & FDI & ODA & GOV & AGR & P2005 & ALLF & INF & LAGF & GDP & POP \\
\hline FDI & 1.0000 & & & & & & & & & \\
\hline ODA & $0.2082 *$ & 1.0000 & & & & & & & & \\
\hline GOV & $0.2064^{*}$ & $-0.2441^{*}$ & 1.0000 & & & & & & & \\
\hline AGR & $0.6038^{*}$ & $0.1869 *$ & $0.3143^{*}$ & 1.0000 & & & & & & \\
\hline P2005 & $0.1582^{*}$ & $0.1660^{*}$ & -0.0085 & $0.1801^{*}$ & 1.0000 & & & & & \\
\hline ALLF & $0.3866^{*}$ & -0.0161 & $0.2566^{*}$ & $0.3173^{*}$ & $0.1064^{*}$ & 1.0000 & & & & \\
\hline INF & -0.0242 & -0.0068 & -0.0515 & -0.0266 & 0.0105 & -0.0101 & 1.0000 & & & \\
\hline LAGF & $0.8078^{*}$ & $0.2181 *$ & $0.2081^{*}$ & $0.6103^{*}$ & $0.1646^{*}$ & $0.3834^{*}$ & -0.0224 & 1.0000 & & \\
\hline GDP & $0.6244^{*}$ & $0.0800^{*}$ & $0.2971^{*}$ & $0.7043^{*}$ & $0.1688^{*}$ & $0.4480^{*}$ & -0.0170 & $0.6242 *$ & 1.0000 & \\
\hline POP & $0.5039^{*}$ & $0.2193^{*}$ & $-0.2800^{*}$ & $0.4922^{*}$ & 0.0313 & $0.2964 *$ & 0.0147 & $0.5042^{*}$ & $0.7564 *$ & 1.0000 \\
\hline
\end{tabular}

TABLE IV: REGRESSION ANALYSIS

\begin{tabular}{|c|c|c|c|c|}
\hline & MODEL 1 & MODEL 2 & MODEL 3 & MODEL 4 \\
\hline & RANDOM-EFFECT & POOLED-OLS & RANDOM-EFFECT & FIXED-EFFECT \\
\hline \multirow[t]{2}{*}{ ODA } & $0.041 * * *$ & $0.037 * * *$ & $0.037 * * *$ & -0.016 \\
\hline & $(3.83)$ & $(2.94)$ & $(2.94)$ & $(-1.03)$ \\
\hline \multirow[t]{2}{*}{ LAGF } & $0.667 * * *$ & $0.646 * * *$ & $0.646 * * *$ & $0.266^{* * * *}$ \\
\hline & $(49.67)$ & $(39.70)$ & $(39.70)$ & $(12.84)$ \\
\hline \multirow{2}{*}{ GDP } & $0.200 * * *$ & $0.065 * *$ & $0.065^{* *}$ & $0.192 *$ \\
\hline & $(11.26)$ & $(2.00)$ & $(2.00)$ & (1.88) \\
\hline \multirow[t]{2}{*}{ POP } & 0.005 & $0.076^{* * *}$ & $0.076 * * *$ & 0.231 \\
\hline & $(0.30)$ & $(2.63)$ & $(2.63)$ & $(0.73)$ \\
\hline \multirow[t]{2}{*}{ GOV } & & $0.043 * *$ & $0.043 * *$ & $0.191 * * *$ \\
\hline & & $(2.02)$ & $(2.02)$ & $(2.90)$ \\
\hline \multirow{2}{*}{ AGR } & & $0.080 * * *$ & $0.080 * * *$ & $0.057^{*}$ \\
\hline & & $(4.44)$ & $(4.44)$ & (1.84) \\
\hline \multirow[t]{2}{*}{ P2005 } & & 0.012 & 0.012 & $0.061 * * *$ \\
\hline & & $(0.98)$ & $(0.98)$ & $(3.35)$ \\
\hline \multirow[t]{2}{*}{ ALLF } & & $0.059 * * *$ & $0.059 * * *$ & $0.037 * *$ \\
\hline & & $(4.43)$ & $(4.43)$ & (1.99) \\
\hline \multirow[t]{2}{*}{ INF } & & -0.003 & -0.003 & 0.000 \\
\hline & & $(-0.24)$ & $(-0.24)$ & $(0.04)$ \\
\hline $\mathrm{N}$ & 3128 & 2262 & 2262 & 2262 \\
\hline R2(WITHIN) & 0.1293 & & 0.1380 & 0.1688 \\
\hline (BETWEEN) & 0.9617 & & 0.9485 & 0.7611 \\
\hline (OVERALL) & 0.6714 & 0.6984 & 0.6984 & 0.6028 \\
\hline
\end{tabular}

Standardized beta coefficients; $\mathrm{t}$ statistics in parentheses

$* p<0.1, * * p<0.05, * * * p<0.01$

TABLE IV: HYPOTHESIS TEST

\begin{tabular}{|c|c|c|c|}
\multicolumn{5}{|c|}{ TABLE IV: HYPOTHESIS TEST } \\
\hline VARIABLE & HYPOTHESIS & EXPECTED SIGN & RESULTED SIGN \\
\hline ODA & HYPOTHESIS 1 & $(+)$ & SPUUPORTED $(+)$ \\
\hline GOVERNANCE & HYPOTHESIS 2 & $(+)$ & SPUUPORTED $(+)$ \\
\hline POLITICAL FACTOR & HYPOTHESIS 3 & $(+)$ & SPUUPORTED $(+)$ \\
\hline \multirow{3}{*}{ ECONOMICAL FACTOR } & HYPOTHESIS 4A & $(+)$ & SPUPPORTED $(+)$ \\
\cline { 2 - 4 } & HYPOTHESIS 4B & $(-)$ & REJECTED $(-)$ \\
\cline { 2 - 4 } & HYPOTHESIS 4C & $(+)$ & SPUPPORTED $(+)$ \\
\cline { 2 - 4 } & HYPOTHESIS 4D & $(+)$ & SPUPPORTED $(+)$ \\
\cline { 2 - 4 } & HYPOTHESIS 4E & $(+)$ & SPUPPORTED $(+)$ \\
\hline
\end{tabular}

\section{CONCLUSION AND IMPLICATION}

I was found that a variety of factors can affect the foreign investment and overseas expansion of Korean companies.
The ODA of the Korean government by executing the investment of Korean companies also increased. This is described together with the assertion of [9] that can aid to the role of the vanguard effect of private investment. Through 
assistance, in which is possible to secure a bridgehead for the expansion of domestic enterprises and the growing influence of private investment in the country. Also Korean companies are to invest upon the governance level. It is an important factor has been revealed. About ratification of economic agreements are political factors were also confirmed by a significant variable, is located in the diplomatic relationship between South Korea. The partnership between the two countries will also affect the investment of the company. To adjust the conflict and conflict of investment between countries, investment guarantee agreement holds to some extent the loss of investment risk potential. As a result, companies will prefer to invest in countries with minimal risk has been confirmed for the best interests of the company. Also economic factors, it was found to affect aggressive investment Korean companies. In this study, I have a limit, such as the following. It is possible to look for were analyzed on the basis of the total amount of money that the Korean companies to invest abroad earlier, precision is slightly reduced. Second, I eliminated the analysis of the investment content of the detailed business of assistance business individual. That is, because they are based on empirical analysis, we can see the deficiencies in content specific analysis through examples and qualitative characteristics of each business. Finally, by the effect from positive foreign investment, it would be done more in the future as in the discourse of neo-liberal economics.

\section{REFERENCES}

[1] D. Moyo, Dead Aid: Why Aid Is not Working and How There Is a Better Way for Africa, Macmillan, 2009.

[2] H. J. Dunning, "Toward an eclectic theory of international production: some empirical tests," Journal of International Business Studies, vol. 11, no. 1, pp. 9-31, 1980 .

[3] J. H. Dunning, "The eclectic paradigm of international production: A restatement and some possible extensions," Journal of International Business Studies, issue 19, Spring 1988.

[4] J. H. Dunning, Regions, Globalization, and the Knowledge-Based Economy, Oxford University Press, 2002.

[5] B. F. Massell, S. R. Pearson, and J. B. Fitch, "Foreign exchange and economic development: an empirical study of selected Latin American countries," The Review of Economics and Statistics, pp. 208-212, 1972.

[6] H. Philipp and L. Matthias, "Aid, governance, and private foreign investment," Economic Journal, vol. 116, no. 513, pp. 773-790, 2006.

[7] U. M. Karakaplan, N. Bilin, Sayek, and Selin, "Aid and foreign direct investment: International evidence," Bilkent University Discussion Papers 0505, Ankara-Turkey: Bilkent University, 2005.

[8] P. Janský, "Aid and foreign direct investment: substitutes, complements or neither?" Int. J. Trade and Global Markets, vol. 5, no. 2, 2012.
[9] H. Kimura and Y. Todo, "Is foreign aid a vanguard of FDI? A gravity equation approach,” Research paper, Research Institute of Economy, Trade and Industry, Tokyo, Japan, 2007.

[10] M. Yasin, "Official development assistance and foreign direct investment flows to Sub-Saharan Africa," African Development Review, vol. 17, no. 1, pp. 23-40, 2005.

[11] S. Blaise, "On the link between Japanese ODA and FDI in China: A microeconomic evaluation using Conditional Logit analysis," Applied Economics, vol. 37, pp. 51-55, 2005.

[12] P. Selaya and E. R. Sunesen, "Does foreign aid increase foreign direct investment?" Working Paper, 2012.

[13] K. Daniel and A. Kraay, "Governance indicators: Where are we, where should we be going?" TheWorld Bank Research Observer, vol. 23, no. 1, pp. 1-30, 2008.

[14] Q. Alam, M. E. UllahMian, and Robert. F. I. Smith, "The impact of poor governance on foreign direct investment: The Bangladesh experience," in Proc. Network of Asia-Pacific Schools and Institutes of Public Administration and Governance (NAPSIPAG) Annual Conference, Beijing, 5-7 December, 2005.

[15] Gangi, Y. Ali, and R. S. Abdulrazak, "The impact of governance on FDI flows to African countries," World Journal of Entrepreneurship, Management and Sustainable Development, vol. 8, no. 3, pp. 162-169, 2012.

[16] G. Steven and D. Shapiro, "Global foreign direct investment flows: The role of governance infrastructure,"World development, vol. 30, no. 11, pp. 1899-1919, 2002.

[17] O. Anis, Y. Saidi, and H. Ghadri, "Governance and foreign direct investment in developing and developed countries," Economics Bulletin, vol. 32, no. 4, 2012.

[18] J. L. Staats and G. Biglaiser, "Foreign direct investment in Latin America: the importance of judicial strength and rule of law1," International Studies Quarterly, vol. 56, no. 1, pp. 193-202, 2012.

[19] N. M. Jensen, "Democratic governance and multinational corporations: Political regimes and inflows of foreign direct investment," International Organization, vol. 57, no. 3, pp. 587-616, 2003.

[20] N. M. Jensen, Nation-States and the Multinational Corporation: A Political Economy of Foreign Direct Investment, Princeton University Press, 2008.

[21] Q. Li, "Democracy, autocracy, and expropriation of foreign direct investment," Comparative Political Studies, vol. 42, no. 8, pp. 1098-1127, 2009.

[22] Q. Li and A. Resnick, "Reversal of fortunes: Democratic institutions and foreign direct investment inflows to developing countries," International organization, vol. 57, no. 1, pp. 175-212, 2003.

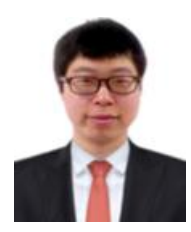

Geon Woo Park was born in Mir-Yang City, Korea on January 1, 1988. He received the bachelor degree in public administration. And he is currently a master course student at the Public Administration of Yonsei University, Korea. His major research is on comparing the states such as foreign direct investment, official development assistance, trade and national competitiveness with diverse perspective and statistical econometrics. He served military service from 2007 to 2009 and worked at KIPA, Korea Institute of Public Administration, from April 2012 to September 2014 as a research assistant. 